\title{
МЕТОДИКА И РЕЗУЛЬТАТЫ ОПРЕДЕЛЕНИЯ ВЛИЯНИЯ ТЕХНОГЕННЫХ ФАКТОРОВ НА ПОДЗЕМНЫЕ ВОДЫ В КАРСТОВЫХ РАЙОНАХ НА ПРИМЕРЕ ПАНДИВЕРЕСКОЙ ВОЗВЫШЕННОСТИ
}

Районы интенсивного развития карста характеризуются нестабильностью поверхностного стока, даже отсутствием местами постоянной гидрографической сети. Проникающая через карстовые воронки поверхностная вода образует поток грунтовых вод, который через тектонические трещины попадает в более глубокие межпластовые горизонты или выходит на поверхность земли в виде родников. Водные ресурсы в таких районах не защищены природой от техногенного влияния. В то же время геологические и гидрогеологические условия способствуют формированию в этих нечерноземных районах необычайно плодородных почв, оптимального для растениеводства водного режима, а следовательно, и интенсивного развития сельскохозяйственного производства. Поэтому для дальнейшего развития народного хозяйства и качественного водоснабжения карстовых районов огромное значение приобретает рациональное использование и охрана имеющихся водных ресурсов.

В условиях Эстонской ССР карст развивается на выходах ордовикских и силурийских пород, реже - на верхнедевонских трещиноватых карбонатных породах. Так, основные карстовые районы распространены в северной части республики и на островах. Благодаря хорошей гидролого-гидрогеологической изученности Пандивереской возвышенности типичного примера карста - оказалось возможным разработать методику определения влияния техногенных факторов на карстовые воды и выявить динамику изменений в состоянии водных ресурсов за 19741984 гг. в этом районе.

Исследования в целях установления состояния водных ресурсов Пандивереской возвышенности начались в 60-х годах. Управление геологии ЭССР ведет режимные наблюдения за подземными водами в этом районе с 1968 г., а с 1981 г. - за химическим составом родниковых вод. Параллельно составлялись крупномасштабные мелиоративно-гидрогеологические и инженерно-геологические карты возвышенности. В 1974 г. приступили к оценочным работам. На их основе был составл̈ен первый сводный обзор по охране водных ресурсов Пандивереской возвышенности (Аruја и др., 1976). В 1978-83 гг. изучалось состояние водных ресурсов в пределах сельскохозяйственных угодий возвышенности в целях их рационального использования (Kink, 1978, 1982; Lust, Tuuga, 1982).

Происхождение Пандивереской возвышенности (абс. отм. до 160 м) считается денудационно-экзарационным (Карукяпп, Таваст, 1985). Четвертичный покров в пределах возвышенности маломощный (обычно 25 м) и представлен в основном ледниковыми отложениями. Мощность ордовикско-силурийских карбонатных пород превышает 100 м. Эта толща (абс. отм. поверхности коренных пород составляет 120-130 м) изобилует трещинами, встречаются отдельные сбросы, флексуры и зоны нарушения (Вахер, 1983). Наличие трещин в карбонатных породах спо- 


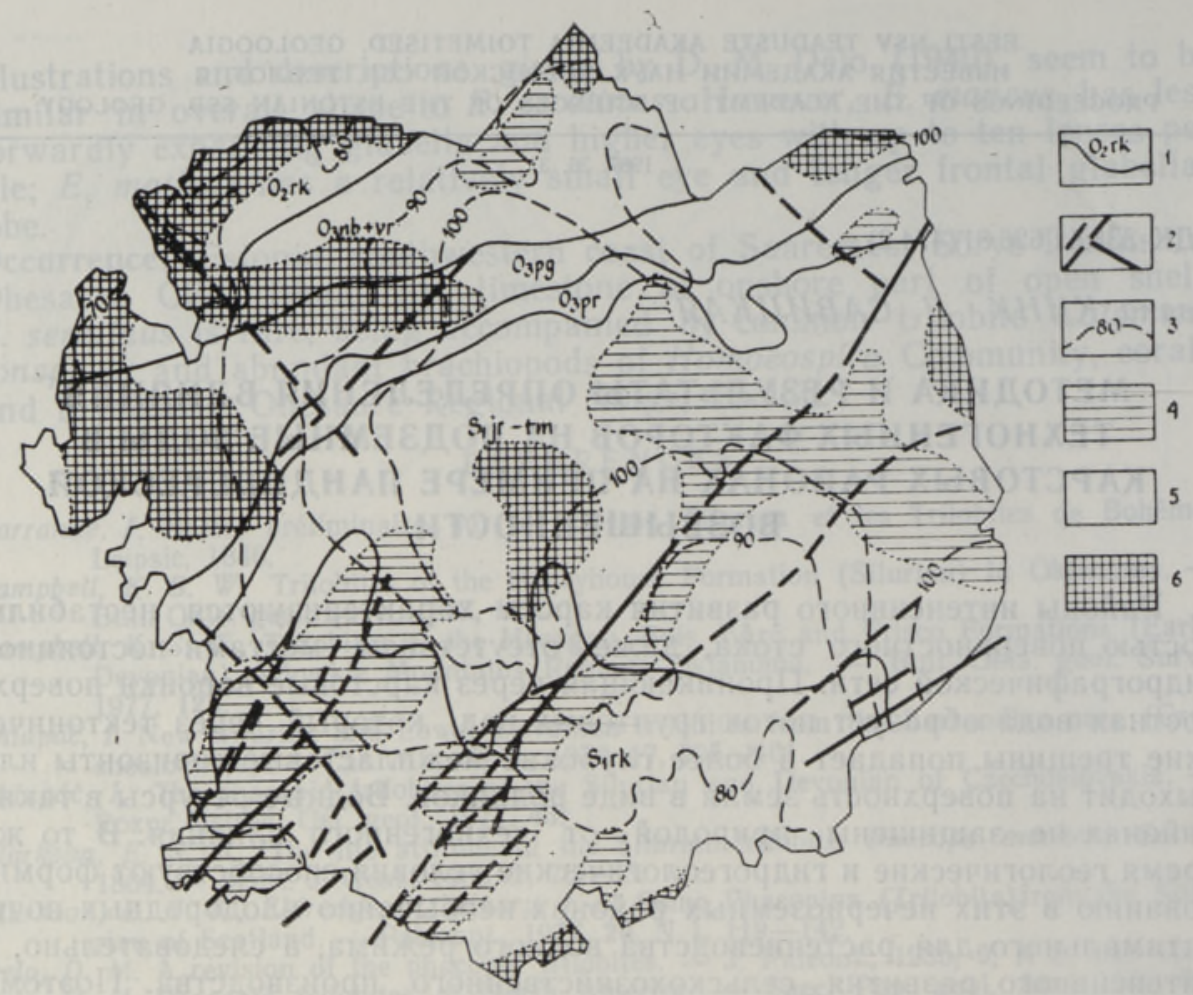

Рис. 1. Гидрогеологические условия на Пандивереской возвышенности. $1-$ граннцы стратиграфических единиц, 2 - тектонические нарушения (установленные и предполагаемые), 3 - гидроизогипсы ордовикско-силурийского водоносного комплекса.

Водопров оди м ость, м²/сут: $4->500,5-500-100,6-<100$.

собствовало широкому развитию современного и древнего карста, общее число карстовых полей и участков (рис. 2) превышает 150 (Хейнсалу, 1982). В результате на своде возвышенности гидрографическая сеть отсутствует, а озера формируются только во время половодья. На склонах возвышенности истоки рек изобилуют карстовыми родниками, дебит которых достигает 200-300 л/с (Эйпре, 1981). Подземная вода в основном приурочена к ордовикско-силурийскому комплексу, водообильность которого резко возрастает в зоне тектонических нарушений (рис. 1). На своде и склонах возвышенности подземные воды либо не защищены, либо защищены слабо. Поскольку такие незащищенные участки распространены по всему своду мозаично и к тому же они совпадают с подземными участками повышенной водопроводимости, техногенное влияние на подземные воды регистрируется повсеместно (рис. 1 и 2).

Для выявления техногенной нагрузки на водные ресурсы Пандивереской возвышенности нами применен системный подход с учетом всех природных и антропогенных показателей административных единиц. В сводную оценочную классификацию включены все основные факторы подземной гидросферы: запасы подземных вод, их защищенность, гидродинамические и гидрохимические особенности карстовых районов, поскольку достоверные результаты количественных изменений, которые претерпевает водоотвод под влиянием техногенных факторов, невозможно получить без привлечения геологических и гидрогеологических данных. При определении же природной защищенности подземных вод необходимо учитывать не только показатели гидродинамики зон аэрации и почв, но и состояние поверхностных вод. 


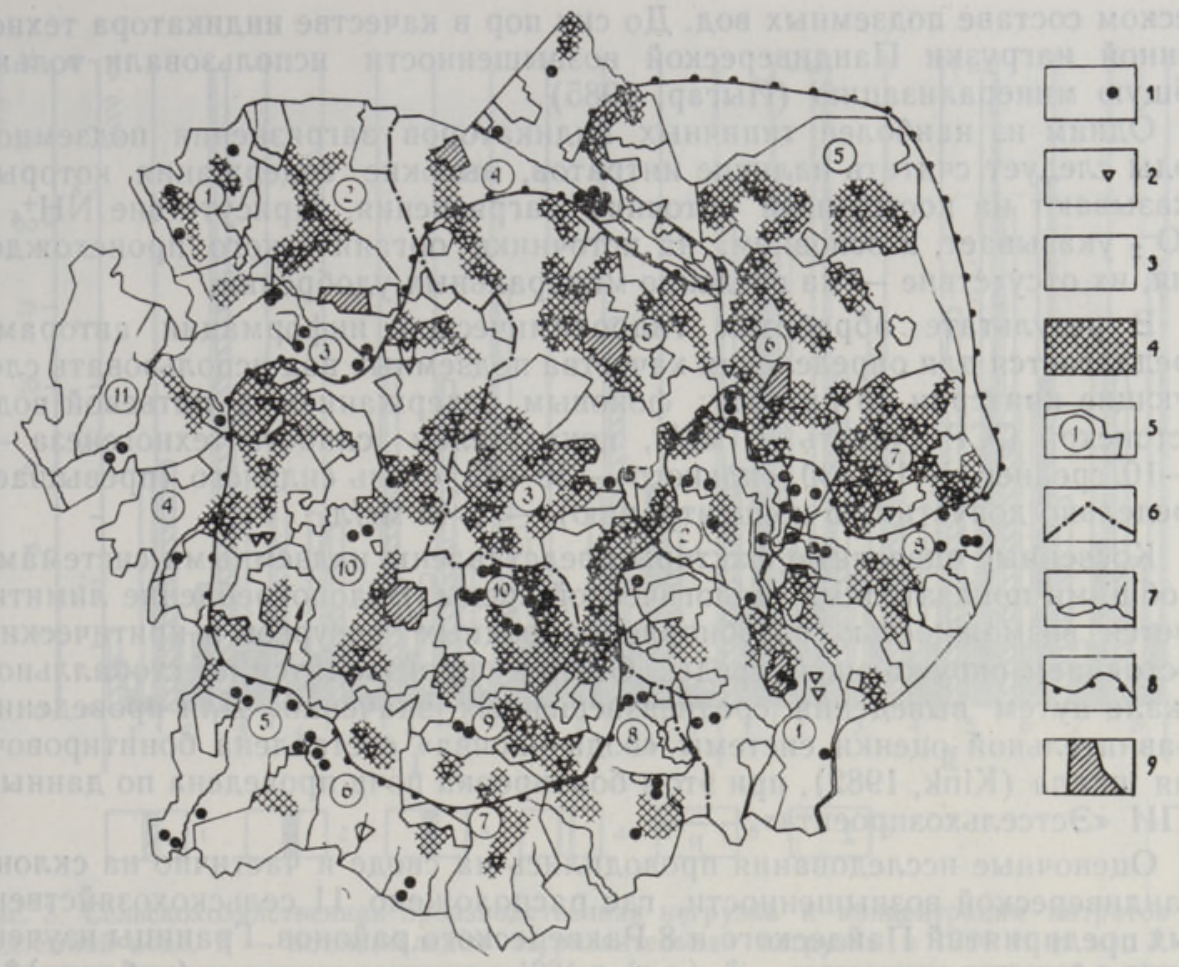

Рнс. 2. Защищенность подземных вод на Пандивереской возвышенности. 1 - родники, 2 - карст, 3 - лес, 4 - подземная вода не защищена, 5 - номер хозяйства, 6 - граница района, 7 - гидрографическая сеть (временная и постоянная), 8 - свод Пандивереской возвышенности, 9 - населенный пункт.

Техногенные показатели оценивали для 1974 и 1984 гг., учитывая данные водопотребления, водоотвода осушительными системами и техногенной нагрузки. Загрязнения сельскохозяйственного происхождения выражали в человеко-эквивалентах (ч. э., равный 54 г по БПК (Maastik, 1984).

Загрязнительная нагрузка подразделяется на потенциальную и вероятную. Первая зависит от объема производства и высчитывается на животную единицу, вторая выражает количество загрязнительного вещества, попадающего в окружающую среду, т. е. зависит от технологии производства.

Признаком антропогенной деятельности (техногенной нагрузки) считается наличие в составе подземных вод хлоридов, сульфатов и азотсодержащих соединений. Повышенное содержание хлоридов и сульфатов может быть связано с диффузией морских вод, а также с подсосом вод из нижезалегающих более минерализованных водоносных горизонтов. В таких случаях азотсодержащие соединения обычно отсутствуют. Их источниками являются продукты разложения органических веществ и минеральные удобрения. В большинстве случаев участки с повышенным содержанием азотсодержащих соединений в подземной воде совпадают с участками повышенного содержания хлоридов и сульфатов, присутствующих в отходах скотоводства. Необходимо также отметить, что загрязнение вызывает активизацию процесса выщелачивания водовмещающих пород, а это в свою очередь - существенные изменения в хими- 
ческом составе подземных вод. До сих пор в качестве индикатора техногенной нагрузки Пандивереской возвышенности использовали только общую минерализацию (Йыгар, 1985).

Одним из наиболее типичных индикаторов загрязнения подземной воды следует считать наличие нитратов, высокие содержания которых указывают на постоянный источник загрязнения. Присутствие $\mathrm{NH}_{4}^{+}$и $\mathrm{NO}^{-}{ }_{2}$ указывает, в основном, на источники органического происхождения, их отсутствие - на введение минеральных удобрений.

В результате обработки гидрохимической информации авторами предлагается для определения качества подземных вод использовать следующие критерии по нитрату: фоновым содержанием в питьевой воде Эстонской ССР считать 1 мг/л, показателем слабого техногенеза $1-10$, среднего - $10-30$, сильного - 30-45, очень сильного (превышает предельно допустимую концентрацию) $-\geqslant 45$ мг/л.

Косвенные оценочные факторы представлены надземными системами и общими показателями геологической среды. Водопотребление лимитируется возможностью возобновления водных ресурсов и критическим состоянием окружающей среды. Оценка производится по стобалльной шкале путем выведения средневзвешенных значений. Для проведения сравнительной оценки системы «вода-почва» составлена бонитировочная шкала (Kink, 1982), при этом бонтировка почв проведена по данным ГПИ «Эстсельхозпроекта».

Оценочные исследования проводились на своде и частично на склоне Пандивереской возвышенности, где расположено 11 сельскохозяйственных предприятий Пайдеского и 8 Раквереского районов. Границы изученного района установлены по административному принципу (таблица)*.

Источником питьевой воды в изучаемом районе является верхний силурийско-ордовикский водоносный комплекс. По данным 1984 г., суммарное водопотребление района составляло $11000 \mathrm{~m}^{3} /$ сут, в том числе $2750 \mathrm{~m}^{3} /$ сут $(25 \%)$ приходилось на поселки. Число эксплуатационных буровых скважин - 433, их глубина колеблется от 20 до 200 м. Если водопотребление в районе Пандивере в данное время еще не причиняет истощения водоносных горизонтов, то буровые колодца часто становятся источниками загрязнения. При негерметичном тампонировании устьев буровых колодцев загрязненная поверхностная и грунтовая вода попадают в источник водоснабжения, т. е. в эксплуатируемый водоносный горизонт. Не соответствующие требованиям буровые колодца составляют в Пайдеском районе $69 \%$, а в Раквереском - $38 \%$ от их общего числа.

Регулирование водного режима на переувлажненных землях Пандивереской возвышенности связано непосредственно с запасами подземных вод в верхнем водоносном горизонте. Сельскохозяйственные угодья на своде возвышенности (колхоз «Маяк», совхозы «Пыдрангу», «Тамсалу» и «Трийги») в осушении практически не нуждаются, т. е. земли мелиоративного фонда отсутствуют. В этих хозяйствах основной проблемой при проведении культуртехнических мероприятий является охрана карстовых форм рельефа. Ликвидация вре́менных карстовых озер или других карстопроявлений может стать причиной заболачивания сельскохозяйственных земель. Отсутствие водоприемников затрудняет осушение небольших (до 50 га) избыточно увлажненных массивов. К сожалению, карстовые воронки не могут служить водоприемниками, так как качество отводимых вод не соответствует требованиям, предъявляемым питьевой воде.

Доля земель мелиоративного фонда, питающихся подземной водой, составляет на склоне возвышенности $50 \%$, в хозяйствах этого района -

* Нумерация хозяйств в таблице соответствует нумерации на рисунках, 


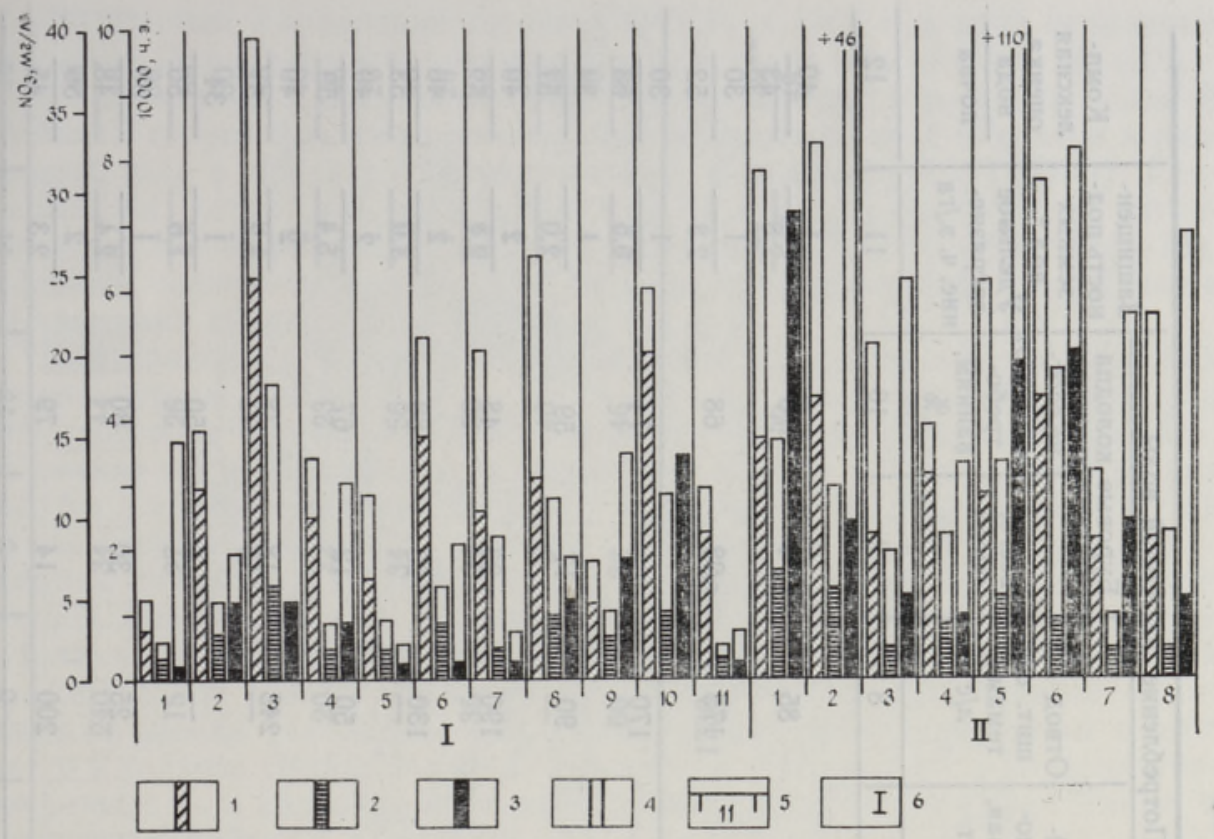

Рис. 3. Сельскохозяйственная производственная нагрузка и концентрация нитратов в подземной воде. 1 - потенциальная загрязнительная нагрузка в 1984 г. (ч. э.), 2 вероятная загрязнительная нагрузка в 1974 г. (ч. э.), 3 - содержание нитратов в питьевой воде в 1974 г. (мг/л), 4 - то же в 1984 г., 5 - номер хозяйства, 6 - район (I Пайдеский, II - Раквереский).

$20-30 \%$ от их общей площади. По подсчетам Гидрометслужбы (Эйпре, 1981), общий сток с данного района составляет $1,09 \mathrm{~m}^{3} / \mathrm{c}$ или $34,4 \mathrm{мм} /$ год. В результате осушения сельскохозяйственных угодий и углубления русел водотоков подземный водоотвод составляет $1,9 \mathrm{~m}^{3} / \mathrm{c}$, из этого на Пайдеский район приходится $1,5 \mathrm{~m}^{3} / \mathrm{c}$. Часть (около $75 \%$ ) отводимой воды поглащается вновь карстовыми воронками и трещинами, т. е. происходит перераспределение водных ресурсов по площади. Понижение уровня подземных вод на $2-4$ м (на возвышениях) в окрестностях осушенных земель регистрировалось в основном в результате углубления русел рек на $0,5-1$ м в карбонатные породы (верховья рек Амбла, Ягала, Соодла, Педья, Янийые, Преэди и др.). Техногенное влияние на подземные воды особенно интенсивно на тех отрезках рек, где происходит и природное поглощение поверхностной воды.

Потенциальными источниками загрязнения на Пандивереской возвышенности являются животноводческие производственные центры. Так, по данным 1979-80 гг., число не соответствующих водоохранным требованиям хранилищ в Раквереском районе -81,6\%, в Пайдеском - $62,2 \%$. По сравнению с 1974 г., потенциальная загрязнительная нагрузка, зависящая от объема производства, возросла больше всего в колхозе «Аравете», «Вяйке-Маарья», а также в совхозах «Пыдрангу», «Вао», «Симуна», «Коэру», «Удева»и им. Р. Пяльсона (рис. 3). Вероятная загрязнительная нагрузка увеличилась, помимо вышеназванных хозяйств, и в колхозе «Ярва-Яани». Для сравнения загрязнительной нагрузки хозяйств применяют понятие «удельное загрязнение» (ч. э./га). Самые высокие показатели отмечаются в совхозах «Пыдрангу» и «Тамсалу». Следовательно, техногенная нагрузка (по всем показателям) увеличилась больше всего на своде возвышенности. 


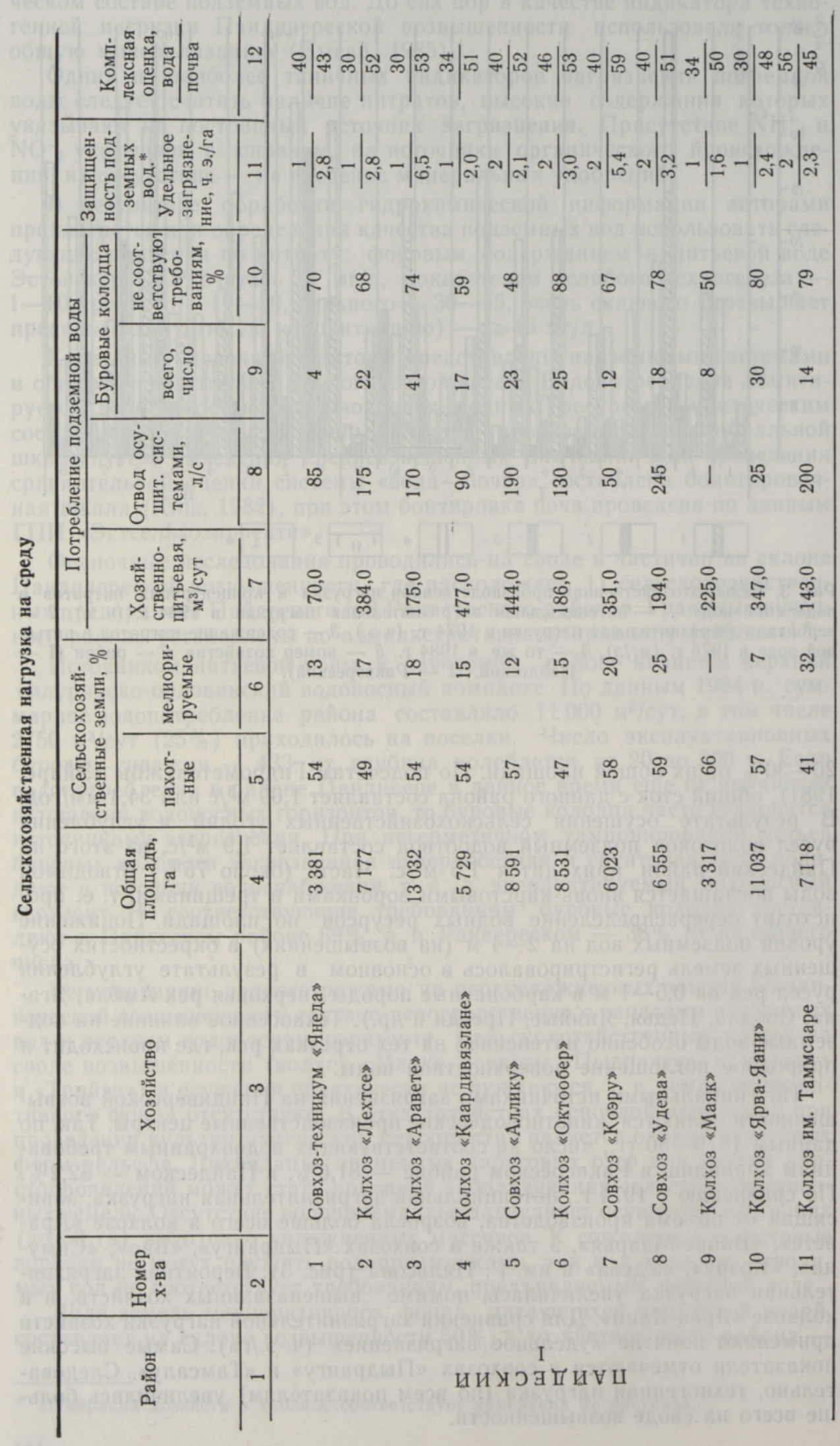




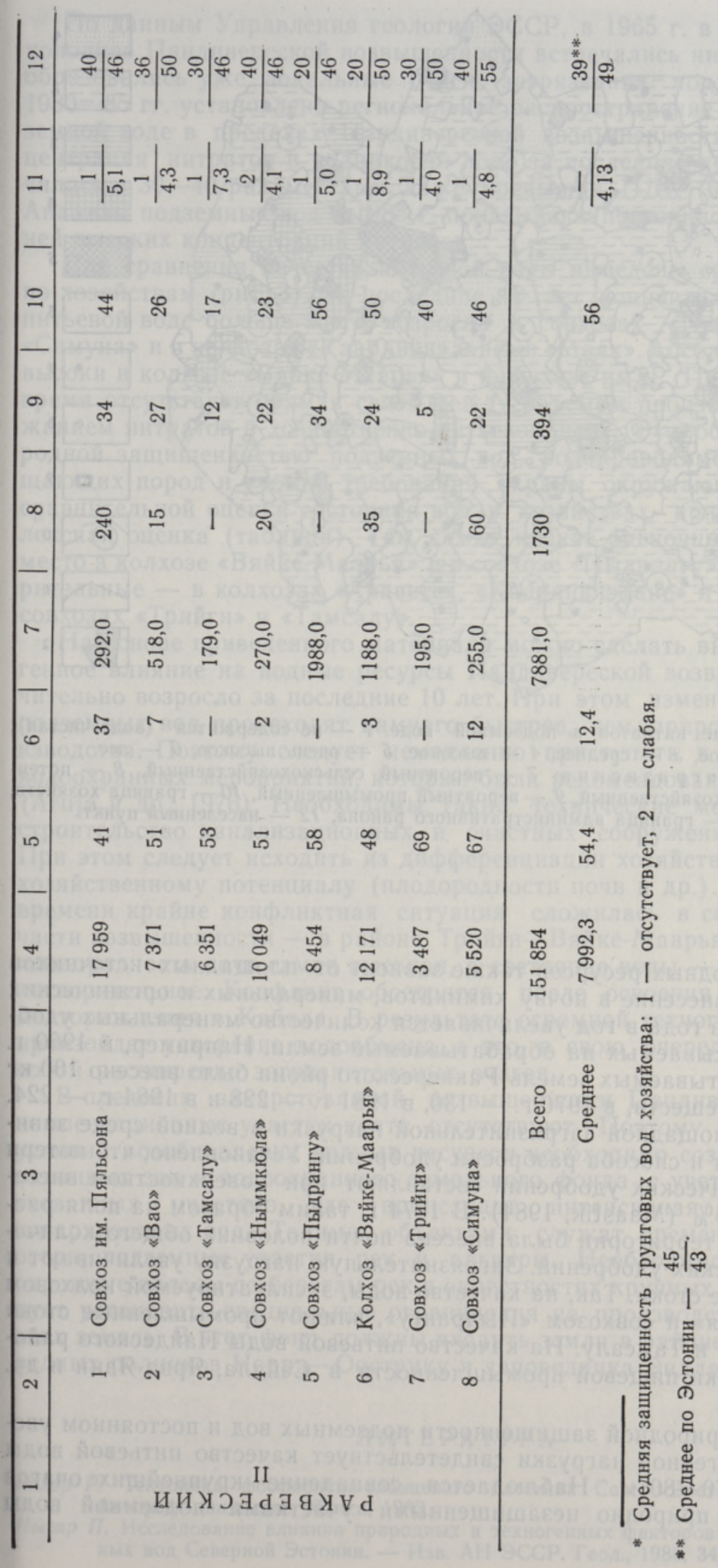




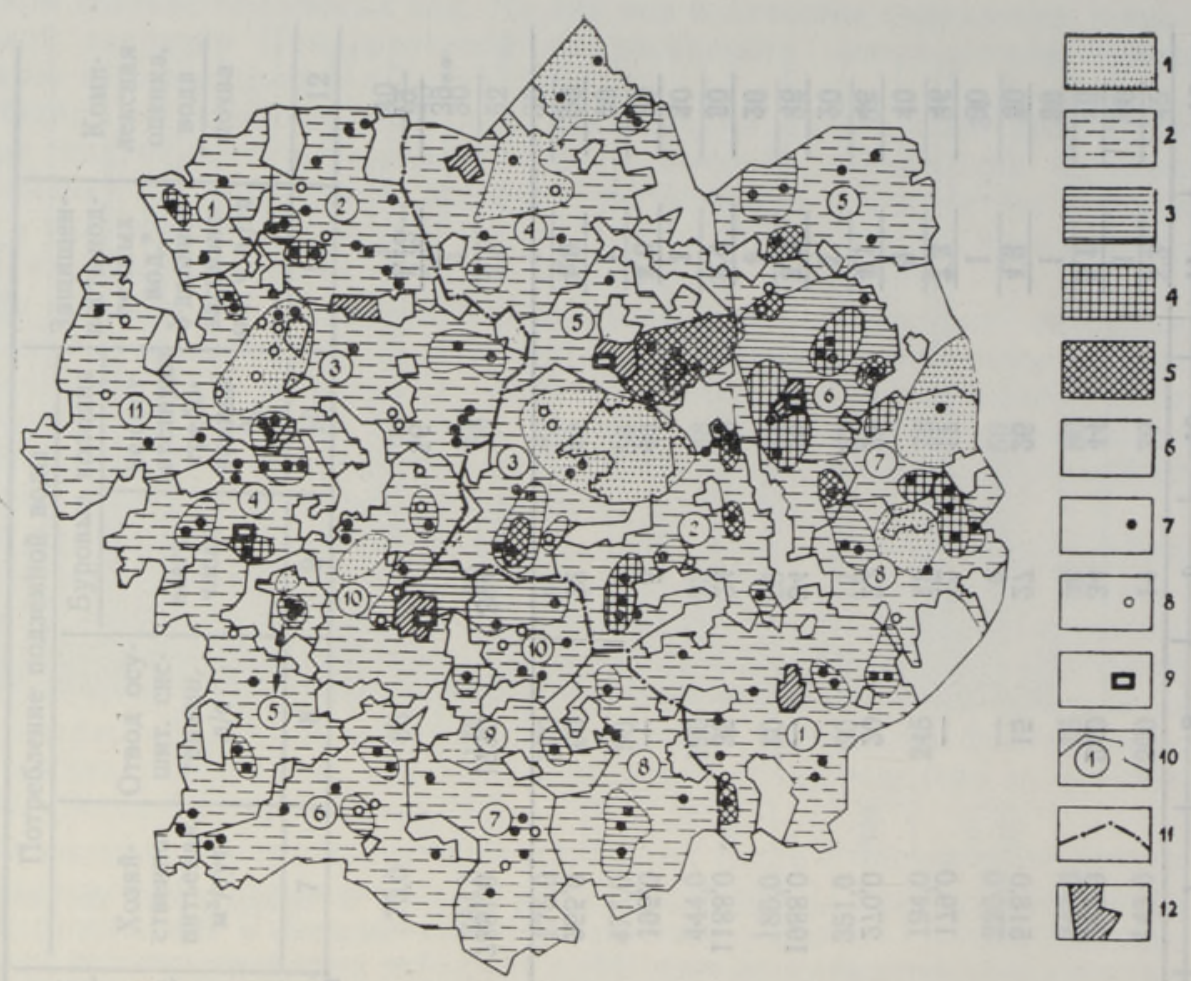

Рнс. 4. Содержание нитратов в подземной воде. 1 - не содержится (вода чистая), 2 - низкое, 3 - среднее, 4 - высокое, 5 - очень высокое, 6 - лес.

Источники 3 агрязнения: 7 - вероятный сельскохозяйственный, 8 - потенциальный сельскохозяйственный, 9 - вероятный промышленный, 10 - граница хозяйств, номер, 11 - граница административного района, 12 - населенный пункт.

Качество водных ресурсов также зависит от площадных источников загрязнения (внесение в почву химикатов, минеральных и органических удобрений). Из года в год увеличивается количество минеральных удобрений, разбрасываемых на обрабатываемые земли. Например, в 1960 г. на 1 га обрабатываемых земель Раквереского рйона было внесено 100 кг усваиваемых веществ, в 1970 г. - 130, в 1981 г. -228 и в 1984 г. -224. Реализация площадной загрязнительной нагрузки в водной среде зависит от времени и способа разброски удобрений. Установлено, что потери азота с органических удобрений составляют при поверхностном внесении на снег $70 \%$ (Maastik, 1984). В 1974 г. таким образом на поля рассматриваемой территории была внесена почти половина общего количества органических удобрений. Загрязнительную нагрузку увеличивают и промышленные стоки. Так, на качество воды, эксплуатируемой колхозом «Вяйке-Маарья» и совхозом «Пыдрангу», влияют промышленные стоки Вяйке-Маарья и Тамсалу. На качество питьевой воды Пайдеского района влияют стоки пищевой промышленности в Сейдла, Ярва-Яани и др. (рис. 4).

О слабой природной защищенности подземных вод и постоянном увеличении техногенной нагрузки свидетельствует качество питьевой воды на глубине $70-80$ м. Наблюдается совпадение крупнейших очагов загрязнения с природно незащищенными участками подземной воды (рис. 2 и 4 ). 
По данным Управления геологии ЭССР, в 1965 г. в воде единичных колодцев Пандивереской возвышенности встречались нитраты. К 1975 г. образовались уже локальные очаги загрязнения подземной воды. В 1980 - 85 гг. установлено региональное распространение нитратов в подземной воде в пределах Пандивереской возвышенности (рис. 4). Концентрация нитратов в родниковой воде за последние десять лет увеличилась в $30-40$ раз, местами даже превышая ПДК (ГОСТ 2874-73). Анализы подземных вод в 1985 г. показывают постоянное присутствие в ней высоких концентраций нитратов.

Для сравнения качества питьевой воды выведены средние значения по хозяйствам (рис. 3). За последние 10 лет концентрация нитратов в питьевой воде больше всего возросла в совхозах «Пыдрангу», «Вао», «Симуна» и в колхозах «Каардивяэлане» и «Маяк». Абсолютные значения высоки в колхозе «Вяйке-Маарья» и в совхозе им. Р. Пяльсона. В то же время отсутствует прямая связь между объемом производства и содержанием нитратов в хозяйственно-питьевой воде. Это обусловлено природной защищенностью подземных вод, водопроводимостью водовмещающих пород и учетом требований охраны окружающей среды. Для сравнительной оценки состояния вод в хозяйствах применяется комплексная оценка (таблица). Так, самые низкие оценочные баллы имеют место в колхозе «Вяйке-Маарья» и в совхозе «Пыдрангу», а неудовлетворительные - в колхозах «Аравете», «Каардивяэлане» и «Ярва-Яани», в совхозах «Трийги» и «Тамсалу».

На основе приведенного материала можно сделать вывод, что техногенное влияние на водные ресурсы Пандивереской возвышенности значительно возросло за последние 10 лет. При этом изменения в качестве подземных вод происходят намного быстрее, чем прирост объема производства. Поэтому следует немедленно приступить к осуществлению водоохранных мероприятий, которые были рекомендованы уже в 1976 г. (Aruja и др., 1976). Необходимы такие технические мероприятия, как строительство канализационных и очистных сооружений и хранилищ. При этом следует исходить из дифференциации хозяйств по их сельскохозяйственному потенциалу (плодородности почв и др.). К настоящему времени крайне конфликтная ситуация сложилась в северо-восточной части возвышенности - в районе Трийги-Вяйке-Маарья-Тамсалу, где плодородность почв самая высокая, а состояние воды - крайне неудовлетворительное. Конфликт обострится после освоения фосфоритового месторождения в Кабала. В результате огромной техногенной нагрузки произойдет ускорение водообмена, а это, в свою очередь, повлечет за собой расширение загрязнительных очагов.

В пределах закарстованной возвышенности Пандивере природные компенсационные участки почти отсутствуют. Поэтому для улучшения условий возобновления водных ресурсов необходимо создать сеть водоохранных зон и водоохранного земельного фонда с учетом всех закарстованных участков, где происходит интенсивная инфильтрация поверхностных вод. Такими объектами служат вре́менные карстовые озера, подземные участки рек и альвары. Необходимо создать водоохранные полосы по берегам рек в окрестностях крупных родников. Следует установить специальные ограничения на производство в пределах этих земель. В этот фонд должны входить земли в районе питания заповедных родников Норра-Оострику и заповедника Эндла.

\section{ЛИТЕРАТУРА}

Вахер P. Тектоника́ фосфоритно-сланцевого бассейна Северо-Восточной Эстонин. Автореф. канд. дис., Мннск, 1983.

Пыгар П. Исследование влияния природных и техногенных факторов на состав подземных вод Северной Эстонии. - Изв. АН ЭССР. Геол., 1985, 34, № 4, 148-156. 
Карукяпn P., Таваст Э. Структура и ледниковый морфогенез Пандивереской возвышенности. - Изв. АН ӘССР. Геол., 1985, 34, № 1, 22-29.

Хейнсалу X. Карст Пандивереской возвышенности и охрана природной среды. - В кн.: Охрана внутренних вод. Уч. зап. ТГУ, вып. 614, Тарту, 1982, 86-91.

Эŭnpe $T$. Водный режнм закарстованной Пандивереской возвышенности Эстонии Л., 1981.

Aruja, M., Eipre, T., Kink, H., Maastik, A., Tšeban, E. Pandivere piirkonna kaitseks. Eesti Loodus, 1976, nr. 9, 548-555; nr. 10, 628-634.

Kink, $H$. Põllumajanduse planeerimise hüdrogeoloogilised tingimused Paide rajoonis. Rmt.: Territoriaalse planeerimise probleeme liiduvabariigi rajoonis. Ettekannete teesid. Tallinn, $1978,48-51$.

Kink, H. Hüdrogeoloogilistest tehistingimustest Rakvere rajoonis. - Rmt.: Loodusvarade kasutamine ja keskkonnakaitse. Tallinn, 1982, 41-50.

Lust, E., Tuuga, V. Pōllumajandusreostus ja pōhjavee seisund Rakvere rajoonis Pandivere kôrgustikul. - Rmt.: Loodusvarade kasutamine ja keskkonnakaitse. Tallinn, $1982,57-63$.

Maastik, A. Veekaitse põllumajanduses. Tallinn, 1984.

Институт геологии
Академии наук Эстонской ССР

\section{Поступила в редакцию 26/II 1986}

\section{Hella KINK, L. SAVITSKAJA}

\section{POHJAVEE MÕJUTATUSE MĂĂRAMISE METOODIKA JA SELLE RAKENDAMISE TULEMUSTEST KARSTI LEVIKU PIRKONDADES}

Metoodika töötati välja Pandivere kõrgustiku piirkonna 1974.-1984. aasta antropogeense koormuse ja pōhjavee seisundi dünaamika andmeil. Rakendati looduslike tingimuste ja tehiskoormuse kompleksset hindamist, kusjuures peale geoloogiliste ja hüdrogeoloogiliste näitajate arvestati veel hüdroloogilisi tingimusi, mulla omadusi ja tootmise iseärasusi.

Pandivere kõrgustikule kui arenenuma pôllumajandustootmisega piirkonnale Eestis on koondunud ka loomakasvatuse tootmiskeskused ja põllumajandussaadusi töötlev tööstus. Kõrgustiku moodustavad siluri-ordoviitsiumi karstunud ja lôhelised lubjakivid. Ohuke pinnakate ei kaitse pōhjavett reostuse eest. Tarbitavas siluri-ordoviitsiumi pōhjaveekompleksi vees on selle tulemusel viimase kümne aasta jooksul suurenenud nitraatide sisaldus kuni 20 korda. Seepärast on vajalik Pandivere kōrgustiku keskosas veekaitse alade loomine, kus kehtestatakse tootmisele keskkonnakaitseliselt range režiim.

Hella KINK, L. SAVITSKAYA

\section{METHODS AND RESULTS OF DETERMINING THE INFLUENCE OF TECHNOLOGICAL FACTORS ON GROUND-WATER IN PANDIVERE UPLAND}

The methods have been worked out according to the data of the anthropogenic load and the dynamics of the state of ground-water of Pandivere Upland in 1974-1984. The complex assessment of natural conditions and the artificial load of the upland was made where together with the geological and hydrogeological factors the hydrological conditions, quality of soil and peculiarities of production were taken into account.

Animal husbandry production centres and agricultural products processing factories are concentrated to Pandivere Upland that is one of the highly developed agricultural regions of Estonia.

The bedrock of Pandivere Upland is formed by karsted Silurian-Ordovician limestones full of joints. The thin surface layer cannot protect ground-water from pollution. Most of the water for local needs is drawn from the Silurian-Ordovician ground-water complex where the concentration of nitrates has increased 20 times in recent ten years. Therefore it is necessary to form water protection areas in the middle part of Pandivere Upland where all industrial and agricultural enterprises must follow strict environment protection rules. 